\title{
Copyleft, Software Livre e Creative Commons: A Nova Feição dos Direitos Autorais e as Obras Colaborativas
}

\author{
Ronaldo Lemos' \\ Sérgio Vieira Branco Júnior ${ }^{2}$
}

\section{Introdução}

Entre os dias 23 e 25 de junho passado realizou-se, na cidade do Rio de Janeiro, o iSummit 2006, encontro dos representantes do Creative Commons, que tem como um de seus principais objetivos discutir os novos rumos do direito autoral. O encontro, organizado pela Fundação Getulio Vargas - Escola de Direito Rio, contou com a participação de ícones do movimento, como os Profs. Lawrence Lessig e James Wales - criador da enciclopédia eletrônica Wikipedia, além do Ministro da Cultura do Brasil, Gilberto Gil.

Como se sabe, a lei brasileira de direitos autorais, Lei no 9.610/98 (doravante designada LDA), é tida pelos especialistas no assunto como uma das mais restritivas de todo o mundo. Ao proibir a cópia irtegral de obra alheia, condutas que se afiguram corriqueiras no mundo contemporâneo sāo, a rigor, contrárias à lei. Por exemplo, diante dos termos estritos da LDA, quando uma pessoa adquire um $\mathrm{CD}$ numa loja, não pode copiar o conteúdo do $\mathrm{CD}$ para seu iPod, o que configura proibição incoerente com o mundo em que vivemos e com as facilidades da tecnologia digital.

$\mathrm{Na}$ verdade, todo o sistema de proteção dos direitos autorais se funda na defesa do autor e na não-utilização de sua obra, exceto mediante expressa autoriza-

Coordenador do CTS - Centro de Tecnologia e Sociedade da FGV - Escola de Direito Rio. Mestre pela Universidade de Harvard e Doutor pela USP - Universidade de São Paulo.

Líder de Projetos do CTS - Centro de Tecnologia e Sociedade da FGV - Escola de Direito Rio. Mestre em Direito Civil pela UERJ - Universidade do Estado do Rio de Janeiro. 
ção legal ou com seu consentimento. ${ }^{3} \mathrm{O}$ fundamento principal é a importância de fornecer ao autor mecanismos de proteção à sua obra, de modo a permitir que seja o autor devidamente remunerado e possa, diante dos proventos auferidos com a exploração comercial de sua obra, seguir produzindo intelectualmente. ${ }^{4}$

Curiosamente, ainda que o sistema legal de direitos autorais seja fundado na proteção do autor, acaba na prática beneficiando o intermediário, ou seja, as gravadoras, as produtoras de conteúdo, entre outros, uma vez que quase sempre os autores transferem a estes o direito de exploração comercial de suas obras.

Dentro de um sistema jurídico que tem a Constituição Federal como filtro interpretativo (como é o nosso caso, no Brasil), é indispensável que as leis infraconstitucionais passem pelas lentes da Constituição. No entanto, nem sempre a reinterpretação das leis infraconstitucionais a partir do prisma constitucional será suficiente para aferir a legitimidade do uso de obras de terceiros, diante dos termos rígidos da LDA. É necessário buscar novos mecanismos para dar segurança jurídica a quem queira se valer de obras alheias.

Um desses mecanismos são as licenças públicas. O objetivo deste artigo é apresentar soluções que, ainda que incipientes se comparadas à estrutura secular e insatisfatória dos princípios legais do direito autoral vigente, encontram-se já ao alcance de todos e abrangem todos os tipos de obras de arte, indistintamente.

Ainda que as licenças públicas nāo possam ser encaradas como o bálsamo universal, acreditamos, entretanto, que podem ser interessante mecanismo de difusão cultural.

\section{Copyright e Copyleft}

Enquanto o copyright é visto pelos mentores originais do copyleft como uma maneira de restringir o direito de fazer e distribuir cópias de determinado traba-

\footnotetext{
3 O Brasil se filia ao sistema continental de direitos autorais. Este se diferencia do sistema anglo-americano do direito autoral, porque "[o] common law manteve-se dentro da visāo dos privilégios de impressāo; nāo foi basicamente afectado pela Revolução Francesa. Isso conduziu a uma certa materialização do direito de autor. A base do direito era a obra copiável; a faculdade paradigmática era a da reprodução (copyright). $\mathrm{O}$ copyright assenta assim principalmente na realização de cópias, de maneira que a utilidade econômica da cópia passa a ser mais relevante que a criatividade da obra a ser copiada". ASCENSĀO, José de Oliveira. Direito do autor e desenvolvimento tecnológico: controvérsias e estratégias. Revista de Direito Autoral - Ano I - Número I, agosto de 2004. Rio de Janeiro: Lumen Juris.

4 É importante esclarecermos que quando se fala em proteção legal de direitos autorais, em nenhum momento se cogita de se verificar a qualidade da obra. Os direitos autorais existem para a proteção das obras que cumpram com os requisitos legais, e não apenas das obras consideradas de qualidade. A definição da qualidade da obra compete à crítica especializada e escapa aos princípios jurídicos. Ao direito compete apenas verificar a presença dos requisitos indispensáveis à proteçāo do bem intelectual. Se presentes, o bem será protegido, independentemente de sua qualidade intrínseca como obra intelectual.
} 
lho, uma licença de copyleft usa a lei do copyright de forma a garantir que todos os que recebam uma versão da obra possam usar, modificar e também distribuir tanto a obra quanto suas versões derivadas. Assim, de maneira leiga, pode-se dizer que copyleft é o oposto de copyright. ${ }^{5}$

Entende-se, a partir da explicação acima, que o copyleft é um mecanismo jurídico para se garantir que detentores de direitos de propriedade intelectual possam licenciar o uso de suas obras além dos limites da lei, ainda que amparados por esta. Por meio das licenças inspiradas no copyleft, aos licenciados seria garantido, de maneira genérica, valer-se das obras de terceiros nos termos da licença pública outorgada.

Ao tratar do tema, Pedro de Paranaguá Moniz e Pablo de Camargo Cerdeira esclarecem a respeito do sistema de copyleft ${ }^{6}$ surgido nos Estados Unidos (e em que se inserem os Creative Commons): ${ }^{\prime}$

[...] É como qualquer licenciamento clássico em que o autor permite apenas o uso de sua obra, mas no copyleft há o licenciamento de outros direitos de forma não-onerosa.

Assim como outros contratos atípicos de origem estrangeira, como factoring ou o franchising, o contrato copyleft deverá, com o uso e a prática, ser admitido pela doutrina e pelos tribunais pátrios sem maiores problemas.

$[\ldots]$

Em breve resumo, as licenças copyleft licenciam os direitos do copyright, mas obrigam todos os licenciados a fazer referência ao autor da obra e a

5e acordo com definição da Wikipedia (www.wikipedia.org). No original, lê-se que "Whereas copyright law is seen by the original proponents of copyleft as a way to restrict the right to make and redistribute copies of a particular work, a copyleft license uses copyright law in order to ensure that every person who receives a copy or derived version of a work can use, modify, and also redistribute both the work, and derived versions of the work. Thus, in a non-legal sense, copyleft is the opposite of copyright."

6 Exemplos práticos do funcionamento do modelo copyleft no Brasil: Projeto Recombo, o sítio da Gravadora Trama, chamado Trama Virtual e o Creative Commons. MONIZ, Pedro de Paranaguá e CERDEIRA, Pablo de Camargo. Copyleft e software livre: uma opção pela razāo - eficiências tecnológica, econômica e social - I. Revista da ABPI, n 70. p. 69. Ao tratar do copyleft, Andrés Guadamuz González informa que "um projeto mais ambicioso é o Creative Commons, que oferece uma variedade de licenças aplicáveis e todo tipo de material criativo. $\mathrm{Na}$ área de biotecnologia, há sugestōes de que o modelo de copyleft seja usado para proteger resultados públicos do genoma humano que estejam sendo colocados em domínio público por pesquisadores, algo que já foi sugerido por um membro do Human Genome Consortium, embora a idéia nunca tenha sido implementada". No original, lê-se que "A more ambitious project is the Creative Commons, which offers a wide range of licences applicable to all sorts of creative material. In the area of biotechnology, there have been some suggestions that the copyleft model could be used to protect the public results of the human genome race that are being placed in the public domain by researchers, something that has been suggested by a leading member of the Human Genome Consortium, although the idea has never been implemented." GONZÁLEZ, Andrés Guadamuz. Viral contracts or unenforceable documents? contractual validity of copyleft licences. Sweet \& Maxwell, 2004, p. 334, v. 26.

MONIZ, Pedro de Paranaguá e CERDEIRA, Pablo de Camargo. Copyleft e software livre: uma opçāo pela razāo - eficiências tecnológica, econômica e social - v. 1. Revista da ABPI, p. 68. 
utilizarem o mesmo modelo de licenciamento nas redistribuições do mesmo original, de cópias ou de versões derivadas. ${ }^{8}$

Aparentemente, não há qualquer impedimento a esse tipo de licenciamento no Brasil, uma vez que as liberdades e restriçōes se dão apenas no plano dos direitos patrimoniais, e não no dos morais. Aliás, os contratos copyleft visam, entre outros detalhes, criar justamente o conceito de direito moral de paternidade dentro do instituto copyright, já presente no ordenamento jurídico brasileiro como direito cogente. Ou seja, no Brasil há até mesmo previsão legal mais favorável a um dos alicerces dos contratos copyleft.

\section{Software Livre}

O copyleft teve sua origem ${ }^{9}$ ainda em meados da década de 80 do século passado, com o surgimento do software livre. Segundo Sérgio Amadeu, ex-diretor presidente do Instituto Nacional de Tecnologia da Informação (ITI), "o movimento de software livre é a maior expressão da imaginação dissidente de uma sociedade que busca mais do que a sua mercantilização. Trata-se de um movimento baseado no princípio do compartilhamento do conhecimento e na solidariedade praticada pela inteligência coletiva conectada na rede mundial de computadores". ${ }^{10}$

É Sérgio Amadeu quem comenta as razōes que levaram ao surgimento do software livre: ${ }^{11}$

Foi a partir da indignação ativa de um então integrante do MIT, Richard Stallman, contra a proibição de se acessar o código fonte de um software, certamente desenvolvido a partir do conhecimento acumulado de tantos outros programadores, que em 1985 foi criada a Free Software Foundation. O movimento de software livre começou pequeno. Reunia e distribuía pro-

\footnotetext{
8 "Pode-se dizer, portanto, que o copyleft em muito se assemelha ao domínio público, já que permite qualquer uso, alteração, cópia e distribuição da obra sem a necessidade de autorização específica do autor, que já a forneceu a todos os interessados por meio de uma licença. Entretanto, distingue-se do domínio público por nāo permitir que as obras derivadas sejam licenciadas de outra forma que nāo segundo o copyleft." MONIZ, Pedro de Paranaguá e CERDEIRA, Pablo de Camargo. Copyleft e software livre: uma opção pela razāo - eficiências tecnológica, econômica e social - II. Revista da ABPI, n 72, p. 21.

9 Pedro de Paranaguá Moniz e Pablo de Camargo Cerdeira esclarecem o significado do termo: "O termo surgiu como uma brincadeira para com o termo copyright, fazendo alusão à sua inversão, mas tem tomado sério corpo jurídico nos dias atuais. O copyleft, surgido nos EUA, nada mais é do que o próprio instituto do copyright em que o autor libera, desde o licenciamento primeiro, os direitos de uso, reprodução, distribuição e, eventualmente, de alteração de sua obra a qualquer interessado. Não traz, de fato, alteraçōes substanciais nos princípios clássicos, salvo o de, por meio de contrato de licença apropriado, permitir tais liberdades." MONIZ, Pedro de Paranaguá e CERDEIRA, Pablo de Camargo. Copyleft e software livre: uma opção pela razão - eficiências tecnológica, econômica e social - v. I. Revista da $A B P I$, p. 68.

10 Disponível em: <http:/www:softwarelivre.gov.br/sofftarelivre/artigos/artigo_02>. Acesso em: 19 fev. 2006.

1 Disponivel em: <http:/uww:soffwarelivre.gov.br/softwarelivre/artigos/artigo_02>. Acesso em: 19 fev. 2006.
} 
gramas e ferramentas livres, com o código-fonte aberto. Assim, todas as pessoas poderiam ter acesso não só aos programas mas também aos códigos em que foram escritos. A idéia era produzir um sistema operacional livre que tivesse a lógica do sistema Unix que era proprietário, ou seja, pertencia a uma empresa. Por isso, os vários esforços de programação eram reunidos em torno do nome GNU (Gnu Is Not Unix).

Para evitar que os esforços do movimento fossem apropriados indevidamente e patenteados por algum empreendedor oportunista, novamente bloqueando o desenvolvimento compartilhado, a Free Software Foundation inventou a Licença Pública Gerai, GPL em inglês, conhecida como copyleft em contraposição ao copyright. Ela é a garantia que os esforços coletivos não serão indevidamente considerados propriedade de alguém. O GPL é aplicável em todas as frentes em que os direitos autorais são utilizados: livros, imagens, músicas e softwares.

Com a difusāo da Internet, o movimento de software livre ganhou o mundo e logrou produzir um sistema operacional livre, completo e multifuncional, o GNU/LINUX. Em 1992, o finlandês Linus Torvald conseguiu compilar todos os programas e ferramentas do movimento GNU em um kernel, um núcleo central, o que viabilizou o sistema operacional. Torvald denominou este seu esforço de Linux, ou seja, "Linus for Unix".

O Gnu/Linux está baseado nos esforços de mais de 400 mil desenvolvedores espalhados pelos 5 continentes e por mais de 90 países. Como bem apontou Moon e Sproull (1999), é extremamente difícil encontrar desenvolvimentos de engenharia comparáveis em extensão, envolvimento de pessoas e alcance geográfico como o empreendido pelo projeto do $\mathrm{Gnu}$ / Linux. A Microsoft, maior empresa de software do planeta, produz o sistema operacional windows e conta em seu quadro funcional com aproximadamente 30 mil funcionários concentrados em sua sede em Seattle, EUA. Em breve, o desenvolvimento e a melhoria anual do GNU/Linux contará com 1 milhāo de programadores. Sāo estudantes, especialistas, amantes da computação, diletantes, gente à procura de fama, empresas em busca de lucro, profissionais de altíssimo nível, entre tantos outros. Dificilmente uma empresa privada terá condições de acompanhar o ritmo de inovações incrementais de uma rede tão variada e tão inteligente.

A partir do texto acima, é fácil perceber que as questōes envolvendo software livre não se centram em peculiaridades técnicas relacionadas ao software, mas sim peculiaridades jurídicas. Há que ficar claro que um software livre não se distingue dos demais em virtude de mecanismos técnicos. Tampouco há que se confundir software livre com software gratuito. ${ }^{12}$

12 É clássica a assertiva de Richard Stallman a respeito de o conceito de liberdade em software dever 
O grande passo dado por Richard Stallman foi na verdade manter o códigofonte do software aberto. Dessa maneira, qualquer pessoa poderá ter acesso a ele para estudá-lo e modificá-lo, adaptando-o a suas necessidades. São as chamadas quatro liberdades fundamentais do software livre: (i) a liberdade de executar o programa, para qualquer propósito; (ii) a liberdade de estudar como o programa funciona e adaptá-lo para as suas necessidades; (iii) a liberdade de redistribuir cópias, de modo que você possa ajudar ao seu próximo e (iv) a liberdade de aperfeiçoar o programa e liberar os seus aperfeiçoamentos, de modo que toda a comunidade se beneficie. ${ }^{13}$

Observe-se que o autor do software não está abrindo mão de seus direitos autorais. Na verdade, o titular está se valendo "dos seus direitos de autor para, através de uma licença, condicionar a fruição desses direitos por parte de terceiros, impondo o dever de respeitar as quatro liberdades fundamentais acima descritas. O software livre, portanto, é produto direto do direito de propriedade do autor sobre o software e consiste em uma modalidade de exercício desse direito, através de uma licença jurídica". ${ }^{14}$

Para garantir a manutenção do software exatamente como "livre", o instrumento é um contrato jurídico chamado de GNU GPL ${ }^{15}$ (GNU General Public License ou Licença Pública Geral GNU). O uso da GNU GPL enseja a formação de redes de contratos, ou de contratos de licenciamento em rede. Aquele que se vale da licença precisa necessariamente permitir o uso de seus eventuais aperfeiçoamentos e modificaçōes: ${ }^{16}$

O exercício das quatro liberdades que constituem o contrato de licenciamento em rede - usar, adaptar, distribuir e aperfeiçoar - tem duplo significado. Para o autor, o licenciante, a cláusula de compartilhamento obrigatório é um voluntário limite que se impõe, uma obrigaçāo que ele mesmo estabelece para seu direito de autor. Nesse sentido, exerce a autonomia da vontade da teoria contratual liberal clássica. O resultado desta

de dinamarqueses defensores do Creative Commons criou a Free Beer - ou cerveja livre -, que embora não seja gratuita, tem a sua fórmula licenciada para quem quiser produzir sua própria cerveja. Vide <http:/oglobo.globo.com jornal/suplementos/informaticaetc/284705562.asp>.

13 LEMOS, Ronaldo; MANZUETO, Cristiane. Software livre e creative commons. Rio de Janeiro: FGV, Escola de Direito, 2005. p. 6.

i4 FALCÃO, Joaquim (et al.). Software livre e administração pública: estudo sobre o software livre comissionado pelo Instituto Nacional de Tecnologia da Informação (ITI). Rio de Janeiro: Lumen Juris, 2006. No prelo.

15 É fundamental mencionar que não há apenas esta licença para a qualificação de software livre. Para efeitos deste trabalho, usamos uma designação genérica apenas para indicar os mecanismos de licença em que o licenciado fica obrigado a licenciar a obra original ou derivada nas condiçōes determinadas pelo licenciante - que é o que nos interessa. Para a Free Software Foundation, o software será considerado livre se seu licenciamento abarcar as quatro liberdades de que tratamos acima.

16 FALCÃO, Joaquim (et al.). Software livre e administraçāo pública: estudo sobre o software livre comissionado pelo Instituto Nacional de Tecnologia da Informaçāo (ITI). Rio de Janeiro: Lumen Juris, 2006. No prelo. 
autolimitação é que, para os futuros indeterminados usuários, os licenciados, estas liberdades convertem-se em direitos. Por sua vez, a contraprestaçāo pela aquisiçāo destes direitos é a obrigaçāo de repassar a futuros usuários indeterminados não só os aperfeiçoamentos e modificações que porventura o próprio usuário venha a fazer no software original, como também a permissão de uso.

Por isso, diz-se tratar-se de um contrato em rede, já que o licenciado de hoje poderá ser o licenciante de amanhã. Dessa forma, alega-se o efeito viral a esse tipo de contrato, "na medida em que a cláusula do compartilhamento obrigatório inocula-se em todos os contratos, fazendo-os partícipes de uma mesma situação". ${ }^{17}$

Sendo assim, o software livre tornou-se o primeiro grande projeto desenvolvido de maneira colaborativa. Hoje, conta com a adesão de milhares de voluntários que aperfeiçoam seus sistemas e aplicativos.

Relevantíssimo ressaltar que nāo é apenas no âmbito privado que vêm sendo adotados softwares livres. São inúmeros os exemplos de adoção do uso do software livre por parte da administração pública, ${ }^{18}$ nas esferas federal, ${ }^{19}$ estadual ${ }^{20}$ e até mesmo municipal. ${ }^{21}$

A respeito do tema, muito já foi dito, mas não custa ressaltar que a realização integral do princípio do open file em sede da administraçāo pública é inerente ao conceito de sociedade aberta e, assim, medida imperativa em um Estado Democrático de Direito.

FALCÃO, Joaquim (et al.). Software livre e administraçāo pública: estudo sobre o software livre comissionado pelo Instituto Nacional de Tecnologia da Informação (ITI). Rio de Janeiro: Lumen Juris, 2006. No prelo.

18 Marcelo Thompson Mello Guimarães, ex-Procurador-Chefe do ITI, no âmbito de sua atividade em referido órgāo, afirmou, quanto aos princípios constitucionais que levam à adoçāo, por parte da administraçāo pública, do software livre: "A idéia de abertura do código se funda também em outros princípios, objetivos e fundamentos constitucional e legalmente positivados, tais como soberania, desenvolvimento nacional, independência nacional, e, especialmente, se relaciona diretamente ao exercício da cidadania [...]". Parecer nº 57/2004-MTMG/PFE/ITI.

ig Vide <www.softwarelivre.gov.br $>$.

20 A título de exemplo, informa o website <www.softwarelivre.gov.br>: "A estratégia de implementar e impulsionar o uso e o desenvolvimento de sistemas de código aberto nos órgãos da administração pública direta e indireta do Paraná foi muito além das expectativas geradas na fase de elaboraçāo do programa no início de 2003. A avaliação é do presidente da Celepar - Informática do Paraná, Marcos Mazoni, que anunciou economia para o Estado da ordem de R\$127,3 milhōes com a política de software livre adotada pelo governo paranaense. Mais da metade desse valor, $R \$ 78,5$ milhōes, é creditada ao uso de software livre no Programa Paraná Digital, da Secretaria da Educação, que está sendo implantado em todas as escolas estaduais." Acesso em: 5 jul. 2006.

21 Como exemplo, pode-se citar a iniciativa da prefeitura de Fortaleza: "A Prefeitura de Fortaleza, dentro de sua política de tecnologia da informação, tem o uso de software livre como uma de suas prioridades. Dentro dessa filosofia, o Grupo Gerencial de Software Livre (GGSL) - que faz parte da estrutura funcional do PNAFM - nomeou uma equipe de técnicos para realizar a escolha da distribuição GNU/Linux a ser utilizada na Prefeitura de Fortaleza." <www.softwarelivre.gov.br>, acesso em: 5 jul. 2006. 
Evidentemente, diz respeito também à soberania (art. 1ํ, I, da Constituição Federal) e à independência nacional (art. $4^{\circ}, \mathrm{l}$ ). Diz respeito à possibilidade de preservação do princípio da dignidade da pessoa humana (art. $1^{\circ}$, III), ao zelar para que as funcionalidades do código que lastreia a Administraçāo Pública não desempenhem tarefas perniciosas ao núcleo duro de direitos dos indivíduos (art. $5^{\circ}$ ).

Sobretudo, diz respeito ao exercício da cidadania (art. $1^{\circ}$, II), que enseja a participação do cidadão na gestão da res pública. A respeito do tema, assim se manifesta - de maneira precisa - Marcelo Thompson Mello Guimarães, ex-Procurador-Chefe do ITI:22

Daí a necessidade de abertura do Estado, que inclui a idéia de abertura dos códigos que lastreiam e estruturam o exercício de suas diversas funçōes e a ligação desta idéia com os conceitos de democracia e de cidadania.

Por outro lado, é bem de se ver que o sistema de licenças com mitigação nas restrições proprietárias, também remonta diretamente ao desenvolvimento nacional e à promoção do bem comum (art. $3^{\circ}$, I e IV), à construção de uma sociedade livre, justa e solidária (art. $3^{\circ}, \mathrm{I}$ ), que ofereça aos indivíduos e à coletividade plenas possibilidades de desenvolvimento, sob os pontos de vista econômico, social e cultural.

Estas possibilidades se relacionam ao conceito de cidadania (que não se resume ao conceito de sufrágio) e se concretizam na exata medida em que o sistema do copyleft promove a ampliaçāo do desenvolvimento científico (art. 218), por meio da pulverização da inovaçāo e do favorecimento da absorção de tecnologia pelo mercado interno (art. 219), potencializa o processo de inclusão digital e a universalização do direito de acesso (arts. $5^{\circ}$, XIX, e 220); direito, este, que, com suas feiçōes atuais, vem se delineando, mesmo, como um novo direito fundamental gerado na Sociedade da Informação.

E se não há dúvidas de que os dispositivos constitucionais abraçam a tutela dos direitos de propriedade intelectual como mecanismo necessário ao desenvolvimento científico e tecnológico do País (art. 5ㅇ, XXVII e XXIX), também não há dúvidas de que prevêem como regra impositiva e princípio geral da Ordem Econômica a função social da propriedade (arts. $5^{\circ}$, XXIII e 170, III), com idêntica finalidade.

Igualmente, previstas pela Constituição estão a livre concorrência e a defesa do consumidor, como fundamentos dessa mesma Ordem (art. 170, IV e $\mathrm{V}$ ), que se ajusta com muito mais fina precisão a um sistema de inovação que privilegia a desconcentração.

\footnotetext{
GUIMARÃES, Marcelo Thompson Mello. Parecer nº 57/2004-MTMG/PFE/ITI
} 
É de se ver que o princípio democrático demanda que o Estado compreenda a exata medida em que diversos preceitos aparentemente contrapostos nas leis e na própria Constituição se entrelaçam na síntese daquele que é o exato momento histórico experimentado pela Sociedade. (grifos no original)

\section{Creative Commons}

Foi a partir do conceito criado em função do software livre que surgiram os demais projetos colaborativos, dos quais o Creative Commons é um dos exemplos mais relevantes. Observe-se que, para todos os fins, não há diferença entre a licença GNU-GPL do Creative Commons (CC-GNU-GPL) e a GNU-GPL tradicional. Por isso, os termos GNU-GPL e CC-GNU-GPL possuem, assim, significado intercambiável. ${ }^{23}$

O Creative Commons é um projeto criado pelo Prof. Lawrence Lessig, da Universidade de Stanford, ${ }^{24}$ e que tem por objetivo "expandir a quantidade de obras criativas disponíveis ao público, permitindo criar outras obras sobre elas, compartilhando-as. Isso é feito através do desenvolvimento e disponibilização de licenças jurídicas que permitem o acesso às obras pelo público, sob condições mais flexíveis". ${ }^{25}$

É o próprio criador do projeto quem introduz a idéia do commons. Afirma que na maioria dos casos commons é um recurso a que as pessoas de determinada comunidade têm acesso sem a necessidade de se obter qualquer permissão. Em alguns casos, a permissão é necessária, mas seria concedida de maneira neutra. São dados os seguintes exemplos: ${ }^{26}$
a) ruas públicas;
b) parques e praias;
c) a teoria da relatividade de Einstein;
d) escritos que estejam em domínio público.

\footnotetext{
FALCÃO, Joaquim (et al.). Software livre e administração pública: estudo sobre o software livre comissionado pelo Instituto Nacional de Tecnologia da Informação (ITI). Rio de Janeiro: Lumen Juris, 2006. No prelo.

24 "Apesar de ser uma iniciativa surgida nos Estados Unidos, o Creative Commons tem caráter global. O Brasil foi o terceiro país a se integrar à iniciativa, logo após a Finlândia e o Japāo. No Brasil, o Creative Commons funciona em parceria com a Escola de Direito da Fundação Getulio Vargas no Rio de Janeiro (Direito Rio), que traduz e adapta ao ordenamento jurídico brasileiro as licenças, inclusive com o apoio do Ministério da Cultura." LEMOS, Ronaldo. Direito, tecnologia e cultura. Rio de Janeiro: FGV, 2005. p. 85.

25 Disponível em <www.direitorio.fgv.br cts > . Acesso em: 20 ago. 2005.

26 LESSIG, Lawrence. Free culture: how big media uses technology and the law to lock down culture and control creativity. New York: The Penguin Press, 2004. p. 19-20.
} 
Lessig aponta ainda alguns interessantes aspectos que separam as idéias de commons das letras "a" e "b" acima das letras "c" e "d":27

A teoria da relatividade de Einstein é diferente das ruas ou praias públicas. A teoria de Einstein é totalmente "não-rival" [no sentido de que não há rivalidade no uso por mais de uma pessoa simultaneamente]; as ruas e as praias não são. Se você usa a teoria da relatividade, há tanto para ser usado depois quanto havia para ser usado antes. Seu consumo, em outras palavras, nāo rivaliza com o meu próprio. Mas estradas e praias são muito diferentes. Se todos tentam usar as estradas ao mesmo tempo (algo que aparentemente acontece na Califórnia com freqüência), então o seu uso das estradas rivaliza com o meu. Engarrafamentos, praias públicas lotadas.

Então, o autor conclui, a respeito do uso potencialmente infinito das obras digitais por terceiros: "se um bem é 'nāo-rival', então o problema restringe-se a saber se há incentivo suficiente para produzi-lo e nāo se há demanda suficiente para seu consumo. Um bem considerado 'não-rival' nāo pode ser exaurido". ${ }^{28}$

A partir do uso do sistema Creative Commons, é possível a autores de obras intelectuais (quer sejam textos, fotos, músicas, filmes etc.) licenciarem tais obras por meio de licenças públicas, autorizando, assim, a coletividade a usar suas obras dentro dos limites das licenças.

Por meio do site <www.creativecommons.org>, é possível ao autor e a outros titulares de direito autoral autorizarem o dounload de um filme, sua exibiçāo pública (incluindo, a seu critério, o circuito comercial) e mesmo o "sampleamento" da obra (que significa modificaçāo e recriaçāo sobre o original). No âmbito do website, é celebrado um contrato entre o titular do direito e aqueles que solicitam autorizaçāo. ${ }^{29}$

Pode-se afirmar que "a adesão a esse sistema [de Creative Commons] cresce diariamente e já inclui nomes como o dos músicos Gilberto Gil, David Byrne e as bandas Beastie Boys e Matmos (da cantora Björk). No campo científico, o Massachusetts Institute of Technology (MIT) registrou trabalhos pelo Creative Commons para promover a difusão da produção acadêmica". ${ }^{30}$

$2-\quad$ LESSIG, Lawrence. The Future of Ideas: the fate of the commons in a connected world. New York: Random House, 2001, p. 21. No original, lê-se: "Einstein's theory of relativity is different from the streets or public beaches. Einstein's theory is fully 'nonrivalrous'; the streets and beaches are not. If you use the theory of relativity, there is much left over afterward as there was before. Your consumption, in other words, does not rival my own. But roads and beaches are very different. If everyone tries to use the roads at the very same time (something that apparently happens out here in California often), then their use rivals my own. Traffic jams; public beaches crowded."

28 LESSIG, Lawrence. The future of ideas. Op. cit., p. 21. No original, lê-se: "If a resource is nonrivalrous, then the problem is whether there is enough incentive to produce it, not whether there is too much demand to consume it. A nonrivalrous resource can't be exhausted."

29 CRESPO, Sílvio. Reforma agrária no audiovisual: Creative Commons: difusāo de obras, memória e produção colaborativa. Revista Sinopse - ano IV, nº 10. p. 60, dez. 2004.

30 CRESPO, Sílvio. Reforma agrária no audiovisual. Op. cit., p. 60. 
No artigo citado, ${ }^{3]}$ consta informação de que até mesmo a BBC de Londres teria anunciado que iria licenciar todo seu acervo histórico sob o símbolo Creative Commons, uma vez que teria percebido ser mau negócio manter centenas de milhares de horas de produção audiovisual sem qualquer acesso. Vê-se, assim, que o Creative Commons não interessa apenas ao artista iniciante ou desinteressado em auferir ganhos financeiros.

Mais recentemente, durante a realização do iSummit, ${ }^{32}$ a Radiobrás anunciou a adesão a uma licença Creative Commons para autorizar o uso de seu conteúdo. Conforme esclarece o próprio website da Radiobrás, ao comunicar a decisāo antes de seu anúncio oficial, seria adotada a licença 2.5 , que permite a reprodução, o uso para obras derivadas e o uso em peças comerciais de tudo o que é publicado sob o endereço www.agenciabrasil.gov.br, mediante a publicação do crédito. ${ }^{33}$

A difusão do Creative Commons permite que, em vez de o autor se valer de "todos os direitos reservados", possa se valer de "alguns direitos reservados", autorizando-se, assim, toda a sociedade a usar sua obra dentro dos termos das licenças públicas por ele adotadas.

Essa solução protege os direitos do autor, que os tem respeitados, ao mesmo tempo que permite, através de instrumento juridicamente válido, o acesso à cultura e o exercício da criatividade dos interessados em usarem a obra licenciada.

O Creative Commons busca efetivar a vontade de disseminação dos trabalhos dos mais diversos tipos de artistas, criadores e detentores de direitos. Por esse motivo, um determinado autor pode optar por licenciar seu trabalho sob uma licença específica, que atenda melhor a seus interesses, podendo escolher entre as diversas opçōes existentes. ${ }^{34}$

De fato, as licenças do Creative Commons podem ser utilizadas para quaisquer obras, ${ }^{35}$ tais como música, filme, texto, foto, blog, banco de dados, compilação, software ou qualquer obra passível de proteção pelo direito autoral. ${ }^{36}$

\footnotetext{
31 CRESPO, Sílvio. Reforma agrária no audiovisual. Op. cit., p. 61-62.

32 Vide, entre outros, Disponivel em: <http: oglobo.globo.com jornal suplementos informaticaetc 284705562.asp >, citado, e em: < http:/oglobo.globo.com jomal/Suplementos Megazine/284427041.asp >.

33 Disponível em: <www.radiobrás.gov.br>. Acesso em: 5 jul. 2006.

34 LEMOS, Ronaldo. Direito, tecnologia e cultura. Op. cit. p. 85.

35 "Embora não tenham sido desenvolvidas para uso em conexão com softwares, as licenças Creative Commons proporcionam uma base sólida para licenciamento em 'uso aberto' de outras manifestaçōes, como textos, músicas, websites e filmes. Uma das licenças é descrita aqui para demonstrar que as idéias por trás do uso aberto e licenciamento de software livre aplicam-se a mais do que apenas softwares. Adicionalmente, as licenças Creative Commons são solidamente construídas e bem escritas: assim, proporcionam bom modelo para aqueles que queiram redigir suas próprias licenças." No original, lê-se que "While not written for use in connection with software, the Creative Commons Licenses provide a solid basis for licensing the 'open source' use of other expressions, including texts, music, web sites, and films. One of these licenses is described here to reflect that the ideas behind open source and free software licensing are applicable to more than just software. Additionally, the Creative Commons Licenses are solidly constructed and well-written: as such, they provide a good model for those who are considering drafting their own open source licenses." LAURENT, Andrew M. Open source and free software licensing. Sebastopol: O'Reilly, 2004, p. 98.

36 $\mathrm{O}$ website <www.creativecommons.org > esclarece detalhadamente o uso das licenças, inclusive em português.
} 
Ao tratar das características das licenças Creative Commons, pode-se afirmar que: ${ }^{37}$

Essas licenças são escritas em três níveis sob o projeto Creative Commons: um nível para leigos, passivel de entendimento por quem não tem formação jurídica, explicando no que consiste a licença e quais os direitos que o autor está concedendo; um nível para advogados, em que a redação da licença se utiliza de termos jurídicos, tornando-a válida perante um determinado ordenamento jurídico; e um nível técnico, em que a licença é transcrita em linguagem de computador, permitindo que as obras sob ela autorizadas no formato digital sejam digitalmente 'marcadas' com os termos da licença, e permitindo que um computador identifique os termos de utilização para os quais uma determinada obra foi autorizada. Esta última modalidade é particularmente importante em face da crescente regulamentação arquitetônica da Internet, e pode permitir no futuro que, mesmo na eventualidade do fechamento completo da rede, ${ }^{38}$ os trabalhos licenciados sob um tipo de licença como esta do Creative Commons possam continuar a ser interpretados como livres por um determinado computador.

As principais licenças são:

\section{Atribuição}

DE:

Quando a obra é licenciada nos termos desta licença, significa que o autor autoriza a livre cópia, distribuição e utilização da obra. Observa-se que, assim, contorna-se o problema do disposto no art. 46, Il, da LDA, referente à cópia integral da obra, já que há autorizaçāo expressa do autor no sentido de se permitir cópia integral da obra.

Além disso, autoriza-se também a elaboração de obras derivadas, eliminando-se a necessidade de licença nos termos do art. 29 da LDA. O autor exige, no entanto, que a obra seja sempre atribuída ao autor original, fazendo-se sempre referência ao nome do autor, o que, inclusive, encontra-se em conformidade com os direitos morais de autor, dentre os quais se inclui o de paternidade.

LEMOS, Ronaldo. Direito, tecnologia e cultura. Op. cit., p. 84.

38 A questão, relevante e atual, é tratada com profundidade por Lawrence Lessig em Code and other laws of the cyberspace. New York: Basic Books, 1999. 


\section{Não a obras derivativas}

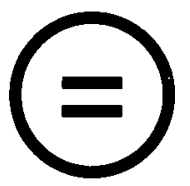

Nos termos desta licença, o autor autoriza a livre cópia, distribuição e utilização da obra, também de modo a se evitar a proibição constante do art. 46, II, da LDA. Diferentemente da licença anterior, entretanto, o autor não autoriza o uso de sua obra para a elaboração de obras derivadas. Por isso, a obra licenciada não poderá ser alterada ou reeditada sem a autorização expressa do autor. É esta licença, portanto, menos ampla do que a anterior, já que o autor não autoriza modificação de sua obra.

\section{Vedados Usos comerciais}

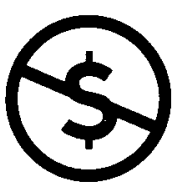

Pelos termos desta licença, o autor autoriza a livre cópia, distribuiçāo e utilização da obra, no que se assemelha à primeira licença analisada. Por outro lado, o autor proíbe o uso da obra com fins comerciais. Dessa forma, as pessoas que tenham tido acesso à obra poderão utilizá-la, nesse particular, apenas em consonância com o já disposto na LDA, que tem por parâmetro o uso de obras sem qualquer intenção de lucro. Permite-se, outrossim, a cópia privada para si e sua distribuição a terceiros, bem como o uso da obra original na elaboração de obras derivadas.

\section{Compartilhamento pela mesma licença}

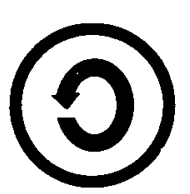

Esta talvez seja a licença que mais amplamente impõe o espírito do Creative Commons. Pelos seus termos, o autor autoriza a cópia, distribuição e utilização da obra, como ocorre nos casos das licenças "atribuição" e "vedados os usos comerciais". No entanto, o autor impōe a condição de que, caso a obra seja utilizada para a criação de obras derivadas, como, por exemplo, texto adaptado em filme, a obra derivada será necessariamente compartilhada pela mesma licença. Ou seja, - licenciamento de uma obra pela modalidade "compartilhamento pela mesma licença" só pode ser utilizado em outras obras se essas outras obras também forem licenciadas sob a licença Creative Commons. 


\section{Recombinação (Sampling)}

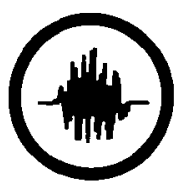

Por esta licença, o autor pode ou não autorizar a livre cópia, distribuiçāo e utilização da obra. De qualquer forma, autoriza sempre a utilização parcial ou recombinação de boa-fé da obra por meio do emprego de técnicas como "sampleamento", "mesclagem", "colagem" ou qualquer outra técnica artística, desde que haja transformação significativa do original, levando à criação de uma nova obra. ${ }^{39}$ A distribuição das obras derivadas fica automaticamente autorizada para o autor que recriou a obra do autor original.

\section{CC-GPL e CC-LGPL}

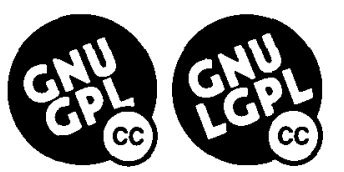

Assim como a licença anterior, estas duas licenças tiveram origem no Brasil, sendo destinadas ao licenciamento de software. As licenças foram desenvolvidas para atender necessidades específicas do governo brasileiro no que tange ao incentivo à adoção do software livre no país. Essas licenças consistem nas tradicionais GPL e LGPL do GNU, isto é, a General Public License e a Lesser General Public Licen$s e,{ }^{40}$ internacionalmente adotadas para o licenciamento de software livre, mas com a diferença de serem estruturadas a partir dos preceitos do Creative Commons. ${ }^{41}$

De modo a atender os interesses dos autores, as licenças Creative Commons podem ser utilizadas em conjunto umas com as outras. Sendo assim, é possível que um autor licencie sua obra com as licenças "não a obras derivativas" e "vedados usos comerciais" simultaneamente.

Juridicamente, as licenças públicas se classificam como contratos atípicos, cuja celebração é autorizada por nosso Código Civil, nos termos de seu art. $425 .^{42}$ Podem ser classificadas também como contratos unilaterais, já que geram direitos e obrigaçōes para somente uma das partes. "Ao licenciar um programa de computador sob o crivo da licença GPL, o licenciante não assume nenhuma obrigação, da

\footnotetext{
39 LEMOS, Ronaldo. Direito, tecnologia e cultura. Op. cit., p. 87-88. A técnica é mais comumente utilizada na área musical.

40 Para maiores detalhes, ver <www.gnu.org >

41 LEMOS, Ronaldo. Direito, tecnologia e cultura. Op. cit., p. 88-89.

42 Art. 425: "É lícito às partes estipular contratos atípicos, observadas as normas gerais fixadas neste Código."
} 
mesma maneira que a utilização de sua obra por terceiros não lhe gera qualquer direito, uma vez que a utilização, distribuição e modificação são gratuitas." 43

De fato, caso determinada obra seja licenciada valendo-se o autor da licença "atribuição" combinada com a licença "vedado o uso comercial", o licenciado poderá fazer cópia da obra e produzir obras derivadas, embora apenas sem intuito de lucro. No entanto, no caso de produzir obras derivadas, deverá sempre indicar o autor original da obra. Ou seja, há obrigação para o licenciado.

Mas é obrigação que pode nem mesmo vir a se configurar (caso o licenciado jamais venha a produzir obra derivada daquela). Afinal, pode ser que a obra derivada jamais venha a existir. E mais: pode ser que, existindo, permaneça inédita, jamais venha a ser licenciada. O que se impōe, tão-somente, é que, existindo obra derivada, se esta vier a ser licenciada, deverá sê-lo pelos termos da mesma licença. Por isso, as licenças públicas Creative Commons serão sempre unilaterais. ${ }^{44}$

Sendo contratos atípicos, ainda assim sobre eles devem incidir os chamados novos princípios contratuais, como a boa-fé objetiva, o equilíbrio econômico e o respeito à sua funçāo social, ${ }^{45}$ sendo-lhes atribuídas as características dos contratos unilaterais. Também é fácil observar sua submissāo às regras da LDA, no sentido de que apenas as faculdades livre e explicitamente licenciadas pelo detentor dos direitos autorais poderão ser aproveitadas por terceiros nos termos da licença. Aqui, também, observa-se com nitidez a causa da licença e o exercício de sua função social na medida em que o licenciado se valha da obra nos exatos termos em que foi autorizado pelo autor.

Por isso, verifica-se que as licenças públicas não são um mecanismo de escape aos princípios erigidos por nosso ordenamento jurídico. Pelo contrário. Sua estrita observância é necessária para não se incorrer em ato ilícito por nāo ter havido autorização expressa por parte do autor. A LDA continua eficaz em meio ao Creative Commons. O que se tem, no entanto, é a garantia de se poder usar a obra alheia dentro das autorizaçōes concedidas.

FALCĀO, Joaquim (et al.). Software livre e administração pública: estudo sobre o software livre comissionado pelo Instituto Nacional de Tecnologia da Informação (ITI). Rio de Janeiro: Lumen Juris, 2006. No prelo.

4 A partir desta análise singela, pode-se afirmar que os negócios jurídicos envolvendo direitos autorais não terāo no sinalagma sua característica principal. Ao contrário, poderāo muito facilmente possuir configuraçāo unilateral, como acabamos de verificar. Por isso, talvez, seja ainda mais importante a análise da causa nos contratos envolvendo direitos autorais, pois a regra, nestes casos, nāo será a bilateralidade. A LDA prevê, em seu artigo 50, caput, que "a cessão total ou parcial dos direitos de autor, que se fará sempre por escrito, presume-se onerosa". Neste caso, haveria bilateralidade, pois a onerosidade necessariamente terá como conseqüência a aferiçāo de um preço justo que comporte o sinalagma. Nos demais casos, entretanto, a lei é silente. Poderá haver pagamento ou nāo. E mesmo no caso do art. 50 citado, há apenas presunçāo que pode ser ilidida. Por isso, é fundamental a verificaçāo precisa da causa do contrato, de modo a ser possivel traçar-lhe as características bem como as conseqüências jurídicas decorrentes de sua celebração.

45 Para noções precisas a respeito da matéria, ver, por todos, Teresa Negreiros, Teoria do contrato: novos paradigmas. Rio de Janeiro: Renovar, 2002. 
Pelos exemplos dados, vê-se que as licenças públicas são instrumentos jurídicos que podem ajudar a difundir a cultura e permitir a expressão nos mais diversos campos sem contudo ferir os direitos autorais de terceiros. E nem se venha a argumentar que os autores estariam abrindo mão de seus direitos patrimoniais no sentido mais estrito do termo. As obras livres não gerariam lucros diretos a partir de seu licenciamento (uma das formas clássicas de remuneração dos autores), mas nem por isso deve-se acreditar que por isso não seriam bem aceitas. Veja-se, a esse respeito, trecho de texto disponível no website consultor jurídico:46

O fato de que homens talentosos como Benjamin Franklin nunca se sentiram estimulados pela perspectiva de retorno material por suas descobertas sempre foi levado em conta no debate sobre os direitos de propriedade intelectual. O historiador Thomas Macauly, por exemplo, que defendia os direitos segundo os princípios clássicos, era obrigado a fazer ressalvas quando mencionava a contribuição que os ricos davam para a criação de obras e inventos: 'Os ricos e os nobres não são levados ao exercício intelectual pela necessidade. Eles podem ser movidos para a prática intelectual pelo desejo de se distinguirem ou pelo desejo de auxiliar a comunidade.' Mas será que a vaidade de produzir uma obra única ou a generosidade de produzir um bem para a comunidade são virtudes exclusivas dos ricos? Boa parte do desenvolvimento artístico parece dizer que não. Pintores importantes como Rembrandt, Van Gogh e Gauguin morreram na pobreza e sem reconhecimento, assim como músicos como Mozart e Schubert e um escritor como Kafka, embora nunca tenha sido verdadeiramente pobre, não chegou a ser reconhecido em vida. Será que a falta de perspectiva de recompensa material em algum momento impediu que eles se dedicassem à música, à pintura ou à literatura? Será que não tinham outro tipo de motivação - a expectativa do reconhecimento póstumo, o simples amor pela sua arte?

Nesse sentido, e ainda sobre o modelo de uso de obras por meio do Creative Commons, é possivel fazer interessantes comentários que bem ilustram o ajustamento das licenças públicas ao sistema hoje vigente: ${ }^{4>}$

No modelo de negociação baseado no copyleft há uma inversão. Ainda no exemplo das obras musicais, o artista grava a sua obra sem grandes recursos e, por isso mesmo, esta pode sair sem a mesma qualidade de uma obra produzida segundo o modelo clássico. A obra licenciada através do copyleft será distribuída livremente, competindo ao autor mesmo, ou a alguma distribuidora, realizar o referido trabalho. Se o material, que foi produzido a um custo muito mais baixo que no modelo clássico, tiver re-

16 Disponível em: <http://conjur.estadao.com.br/static/text/27467,2>. Acesso em: 30 jan. 2006.

4: MONIZ, Pedro de Paranaguá e CERDEIRA, Pablo de Camargo. Copyleft e software livre: uma opção pela razão - eficiências tecnológica, econômica e social - v. I, Op. cit., p. 69 
ceptividade no comércio, outros simpatizantes do modelo copyleft poderão editar a obra, acrescentando em qualidade e agregando valor ao produto. Ao final de um ciclo, ou a obra não se mostra boa o bastante para o gosto comum e é abandonada - risco que se corre também no modelo clássico - ou ela é distribuída e melhorada por terceiros. Assim, o artista original, sem grandes custos, pode acabar por ter sua obra dividida em diversas ediçōes, cada uma de acordo com o interesse de determinado público. Por exemplo: um samba pode se transformar em uma música eletrônica e ser tocado em um ambiente que originalmente nāo comportaria a obra primígena.

[...]

É interessante notar que mesmo no modelo clássico de negociação de obras musicais, o retorno para o artista sobre a vendagem de discos costuma ser muito pequeno. Um exemplo é o contrato de Jimi Hendrix, que previa $2,5 \%$ das vendagens de discos para a banda do artista, incluso aí o valor que ficaria com o famoso guitarrista.

É natural que o direito de autor deva ser preservado. Há autores que dependem da remuneração pelos seus trabalhos para que possam continuar a produzir. O que nāo se quer, acreditamos, é um sistema impositivo em que os autores estejam obrigados a exercer direitos dos quais poderiam, em maior ou menor extensão, abrir mão.

Por isso, acreditamos que iniciativas como o Creative Commons incentivam o desenvolvimento de modelos cooperativos, dentro da lei brasileira, para que autores possam permitir a utilização, divulgação, transformação de sua obra, por terceiros, a fim de contribuir para a ampliação do patrimônio cultural comum e, por conseguinte, para a disseminação da cultura e do conhecimento.

Não obstante isso, o Creative Commnons não se encontra isento de críticas. Alega-se que apenas mascara o rigor do sistema, já que o autor continua detentor dos direitos autorais sobre a obra, e apenas expande - de acordo com o critério de sua exclusiva vontade - o limite de autorização para uso de sua obra.

De qualquer forma, o jornal O Globo publicou em 2005 matéria segundo a qual haveria, então, 4,5 milhōes de obras licenciadas no formato Creative Commons no mundo. E afirma: "não apenas livros ou e-books, mas músicas, filmes, blogs, fotos etc. No Google, há 6,4 milhōes de referências ao Creative Commons e 24 países já adotam essas licenças [...]."48

Mais recentemente, durante o iSummit, Lawrence Lessig informou que há, atualmente, cerca de 140 milhões de obras licenciadas em todo o mundo por licenças Creative Commons.

Ainda que o Creative Commons seja um sistema passível de críticas, acreditamos que possibilita o uso de obras alheias sem o risco de violação de direitos

+\& Jornal O Globo. Caderno Prosa e Verso, de 5 de março de 2005. 
autorais. Além disso, incentiva a criação intelectual e permite que o mundo globalizado trabalhe de maneira mais solidária.

\section{A Revolução das formas colaborativas}

Primo Levi, autor italiano, criou certa vez um personagem chamado senhor Simpson, simpático homem de negócios que oferecia em seu catálogo variado de produtos, dentre outros, máquinas capazes de produzir, automaticamente, versos das formas desejadas, acerca dos temas escolhidos, dispensando o engenho do "autor". 49

Sabe-se que hoje a tecnologia já se encontra bem próxima disso - se é que não queremos admitir que essa realidade já existe. Pelo menos, diante das artes gráficas, os computadores já são capazes da produção independentemente da mão humana.

Diante dessas possibilidades revolucionárias, há que se repensar os conceitos de autor e de usuário da obra intelectual.

Já se entende que o autor não trabalha mais exclusivamente sozinho. É preciso compreender quem é o autor na sociedade da informação. Vários são os exemplos que podem ser invocados: há autores que escrevem livros on line contando com a contribuição dos leitores; programas de televisão que têm seu curso determinado pelos espectadores; usuários da Internet que, diariamente, estão a criar obras derivadas de obras alheias num trabalho infinito e não sem valor artístico e cultural - muito pelo contrário.

Em comunhão com essas considerações, há que se destacar, ainda, que os consumidores da arte há muito não exercem mais papel exclusivamente passivo, mas sim atuam de maneira relevante na disseminação das idéias, na reinvenção do mundo e na integração das diversas culturas, manifestações artísticas e criativas.

É a partir da idéia de atuação conjunta que surge a idéia das obras colaborativas. O conceito não é novo. Na verdade, a concepção da obra em colaboração retoma uma conduta verificada antes da invenção dos tipos móveis. Afirma Eduardo Lycurgo Leite: ${ }^{50}$

Segundo se depreende da obra de Elizabeth L. Eisenstein [The Printing Revolution on Early Modern Europe. Cambridge: Cambridge University Press, 193], até a invenção dos tipos móveis, toda pessoa que repetisse um texto, fosse tal repetição oral, fosse manuscrita, no curso da reprodução do mesmo o alteraria, o que deixava a impressão que o texto pertencia a todo

\footnotetext{
49 Conforme a revista Entre Livros, São Paulo: Duetto ano I, nº 9, p. 70.

50 LEITE, Eduardo Lycurgo. A história do direito de autor no ocidente e os tipos móveis de Gutenberg. Revista de Direito Autoral, Sāo Paulo, ano I, nº II, p. 119, fev. 2005.
} 
mundo, tornando de difícil afirmação que tal texto seria a representaçāo estrita do espírito e propriedade de uma só pessoa, pois afinal o referido texto, de certo modo, representaria a produção da coletividade composta por todas as pessoas que o manusearam, reproduziram e regeneraram ao longo do tempo.

No entanto, o princípio agora é usado não visando violar direitos autorais, nem tampouco ignorá-los. O que existe é, a rigor, o avesso do conceito de autor: o direito do autor fica em segundo plano e muitos participam de obras colaborativas, "porque consideram esta atividade divertida, outros o fazem porque acreditam estar retribuindo conhecimento à sociedade, e outros ainda porque passam a se sentir parte de uma iniciativa global, que pode beneficiar diretamente centenas de milhares de pessoas, senão a humanidade como um todo". ${ }^{51}$

Em seu novo livro, $A$ riqueza das redes (cujo título ecoa o clássico $A$ riqueza das nações, de Adam Smith), o professor da Universidade de Yale, Yochai Benkler, afirma que a emergência das formas colaborativas denota uma independência - como nunca antes fora possível - do processo criativo com relação aos incentivos mercadológicos. O desenvolvimento de blogs e softwares livres, entre outros exemplos que poderíamos citar, ilustram que incentivos nāo mercadológicos sāo tāo ou mais importantes como fatores de fomento à produção intelectual.

Com base nesses preceitos, criou-se a Wikipedia, em janeiro de $2001 .{ }^{52} \mathrm{~A}$ Wikipedia é um grande projeto de criação intelectual que desafia os paradigmas dos direitos autorais. Pondo em xeque os conceitos de autor, de titularidade, de edição e até mesmo de obra, ela pode ser considerada nāo mais uma obra coletiva, mas sim uma obra colaborativa.

Trata-se de uma enciclopédia on line (<www.wikipedia.org $>$ ), em que é possível a todo usuário da Internet fazer qualquer alteração em qualquer verbete, de modo a torná-lo mais preciso ou mais completo, de acordo com seu julgamento.

Sem contar com os problemas engessadores da Enciclopédia Britannica, por exemplo, tais como o tamanho físico que ocupa, o custo de tradução, impressão e distribuição - além, evidentemente, do tempo gasto para revisão e atualização -, a Wikipedia pode ser, ao mesmo tempo, universal e popular.

Dessa maneira, conta com verbetes em 229 línguas e dialetos e com atualidade impressionante, em um total de cerca de 4 milhōes de artigos. ${ }^{53}$ É claro que há defeitos, mas especialistas afirmam que a própria Enciclopédia Britannica os contém em número, por amostragem, quase igual. A revista Nature inglesa submeteu à análise de especialistas 50 artigos científicos da Wikipedia e da Britannica. Entre as 42 revisōes que foram devolvidas à revista, o resultado foi que os especialistas

LEMOS, Ronaldo. Direito, tecnologia e cultura. Op. cit., p. 81-82.

Conforme a revista Época, n" 401, p. 40, 23 jan. 2006.

:3 Conforme www,wikipedia.org, verbete Wikipedia. Acesso em: 5 jul. 2006. 
apontaram uma média de 4 inconsistências por verbete da Wikipedia contra 3 de sua concorrente. ${ }^{54}$

O sistema baseado no conceito de wikis - segundo o qual os usuários podem não apenas acrescentar informações, como nos blogs, mas também editá-las e publicá-las - pode servir a diversos fins de criação. A faculdade de Direito da Fundação Getulio Vargas, no Rio de Janeiro, vem adotando o sistema para uso dos alunos na elaboração de compilações de material revisado pelos próprios alunos a partir das aulas apresentadas em sala.

Além da Wikipedia, diversos outros projetos colaborativos encontram-se em curso. Como exemplo, pode-se citar um projeto mantido pela NASA de catalogação das crateras do planeta Marte. O projeto já catalogou, até o momento, mais de um milhão de crateras e continua aberto para quem quiser analisar as fotografias do planeta. Outro projeto é o Kuro5hin, revista de tecnologia e cultura cuja íntegra da produção editorial é realizada através de sofisticado trabalho colaborativo. ${ }^{55}$

É lógico que não vislumbramos nas formas colaborativas a solução dos problemas derivados do uso de obras alheias protegidas por direitos autorais. Os problemas persistem. No entanto, a Wikipedia é um ótimo exemplo de como os direitos autorais devem ser repensados para se ajustarem à nova realidade do mundo informatizado e muito mais criativo.

As obras colaborativas podem vir a ser, a rigor, a efetivação, dentro do campo de direitos autorais, do disposto no art. $4^{\circ}$, I, de nossa Constituição $\mathrm{Fe}-$ deral, que objetiva a construção de uma sociedade mais solidária, que entende que a liberdade de expressão, a ajuda mútua e o compartilhamento de conhecimento podem valer mais do que a preservação de direitos autorais, muitas vezes, de pouco espectro.

54 Conforme a revista Época, no 401, p. 43, 23 jan. 2006.

55 LEMOS, Ronaldo. Direito, tecnologia e cultura. Op. cit., p. 82. Vejam-se os websites <http://clickworkers.arc.nasa.gov/top e www.kuro5hin.org>. 